\title{
Horner syndrome due to internal carotid artery dissection
}

\author{
Sara Mazzucco, MD; and Nicolò Rizzuto, MD
}

A few hours after a motorcycle accident with multiple rib and right wrist fractures, a 37-year-old man developed transient dysphasia and right hemiparesis associated with left Horner syndrome (figure A). Brain CT scan was normal, but diffusion weighted (DW) MRI disclosed recent ischemia (figure B). Occlusive dissection of left extracranial internal carotid artery (ICA) was demonstrated (figure $\mathrm{C}-\mathrm{E}$ ), and IV heparin infusion was started with a subsequent neurologically uneventful clinical course.

ICA dissection can occur even with unapparent neck injuries ${ }^{1}$; therefore, trauma associated with Horner syndrome should instigate a workup for carotid dissection. $^{2}$

\section{References}

1. Miller PR, Fabian TC, Croce MA, et al. Prospective screening for blunt cerebrovascular injuries: analysis of diagnostic modalities and outcomes. Ann Surg 2002;236:386-395.

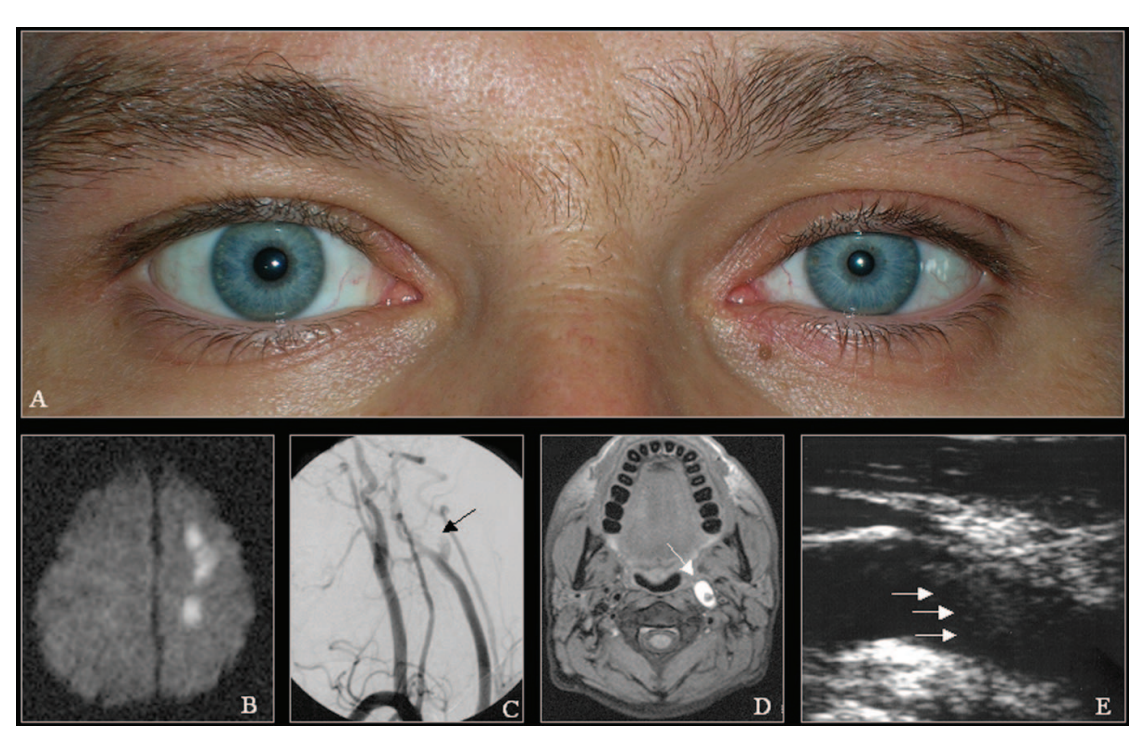

Figure. (A) Horner syndrome (miosis and ptosis). (B) Multiple left frontoparietal acute ischemic lesions on DW MRI. (C) Carotid angiography with evidence of left extracranial ICA occlusion. (D) ICA mural hematoma due to dissection evident on MRI scan. (E) Intimal flap (arrows) appearance on Duplex scan, pathognomonic sign of dissection.

\footnotetext{
2. Chan CC, Paine M, O'Day J. Carotid dissection: a common cause of Horner's syndrome. Clin Experiment Ophthalmol 2001;29:411-415.
}

From the Department of Neurological Sciences and Vision, Section of Clinical Neurology, University of Verona, Italy. Disclosure: The authors report no conflicts of interest.

Address correspondence and reprint requests to Dr. Sara Mazzucco, Clinica Neurologica, Policlinico G.B.Rossi, Piazzale L.A.Scuro,10, 37134 Verona, Italy; e-mail: sara.mazzucco@univr.it 


\section{Neurology}

\section{Teaching NeuroImage: Horner syndrome due to internal carotid artery dissection Sara Mazzucco and Nicolò Rizzuto \\ Neurology 2006;66;E19 \\ DOI 10.1212/01.wnl.0000200954.21276.96}

\section{This information is current as of March 13, 2006}

\section{Updated Information \&} Services

References

Subspecialty Collections

Permissions \& Licensing

Reprints including high resolution figures, can be found at: http://n.neurology.org/content/66/5/E19.full

This article cites 2 articles, 0 of which you can access for free at: http://n.neurology.org/content/66/5/E19.full\#ref-list-1

This article, along with others on similar topics, appears in the following collection(s):

Autonomic diseases

http://n.neurology.org/cgi/collection/autonomic_diseases

Carotid artery dissection

http://n.neurology.org/cgi/collection/carotid_artery_dissection

Information about reproducing this article in parts (figures,tables) or in its entirety can be found online at:

http://www.neurology.org/about/about_the_journal\#permissions

Information about ordering reprints can be found online:

http://n.neurology.org/subscribers/advertise

Neurology ${ }^{\circledR}$ is the official journal of the American Academy of Neurology. Published continuously since 1951, it is now a weekly with 48 issues per year. Copyright. All rights reserved. Print ISSN: 0028-3878. Online ISSN: 1526-632X.

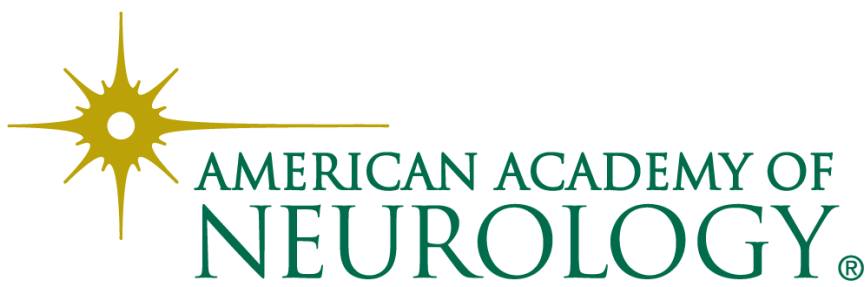

